\title{
Assessment of bacterial contamination of irrigation water and market gardening products at Parakou (A city in northern Benin)
}

\author{
Eric BIO NIKKI SARE ${ }^{1}$, Armelle Sabine Yélignan HOUNKPATIN ${ }^{2,3 *}$, \\ Vidédji Naéssé ADJAHOSSOU ${ }^{4}$, Abdel Fawaz BAGOUDOU ${ }^{1,5}$ et \\ Anicette BIO SOUROU ${ }^{1}$
}
${ }^{1}$ Inter-Regional University of Industrial Engineering, Biotechnologies and Applied Sciences (IRGIB -Africa), 07 PO Box 231 Cotonou, Benin.
${ }^{2}$ Pluridisciplinary Research Laboratory for Technical Education (LaRPET), Technical Advanced Teachers Training College (ENSET), University of Sciences, Technologies, Engineering and Mathematics of Abomey (UNSTIM), PO Box 133 Lokossa, Benin.
${ }^{3}$ Laboratory of Hygiene, Sanitation, Toxicology and Environmental Health (HECOTES), the training Center Interfaculty and Environmental Research for Sustainable Development (CIFRED), University of Abomey (UAC), 01 PO Box 1463 Cotonou, Benin.
${ }^{4}$ National High School of Applied Biosciences and Biotechnologies (ENSBBA) of the National University of Sciences, Technologies, Engineering and Mathematics (UNSTIM) in Republic of Benin.
${ }^{5}$ Interdisciplinary Graduate School of Science and Technology, Shinshu University, 399-4511
Minami Minowa Mura 8304, Japan.
*Corresponding author; E-mail: harmelle2011@gmail.com; Tel.00 (229) 97662855

Received: 23-11-2020 Accepted: 27-02-2021 $\quad$ Published: 28-02-2021

\begin{abstract}
In many districts of Benin, the use of wastewater in urban agriculture is becoming more and more widespread. This activity around wastewater discharges potentially poses health risks to populations. As water is one of the main sources of food contamination in developing countries, the main objective of this study, oriented towards the assessment of the bacterial load, was to search for Salmonella which are pathogenic to humans in irrigation water as well as in some market gardening products consumed in Parakou district. The study was carried out on the market gardening perimeter of the slaughterhouse site located near the international market Arzèkè, where market gardeners exclusively use surface water from the mixture of groundwater and runoff from installed collectors. At the end of this study, the results from the observation of the different colonies, followed by biochemical tests for the detection and differentiation of Salmonella, allowed us to detect the presence of Salmonella in the different samples ranging from $50 \%$ to $80 \%$. The presence of Fecal coliforms and Escherichia coli not only in water but also in market garden products was also confirmed. These results might partly explain the frequency of salmonellosis in the study area.
\end{abstract}

(C) 2021 International Formulae Group. All rights reserved.

Keywords: Salmonella, microbiological tests, biochemical tests. 


\section{INTRODUCTION}

The exponential increase of the population in developing countries is one of the problems facing by the inhabitants. This explains the importance of urban and periurban agriculture, hence the ever-increasing needs for water (Kenmogne et al., 2010). In Sub-Saharan Africa (SSA), it is estimated that $10 \%$ of the population in cities are involved in the practice of wastewater irrigation, with 50\% to $90 \%$ of urban dwellers in West Africa reported to consume vegetables irrigated with wastewater or polluted surface water within or close to cities (Drechsel et al., 2006). Urban and peri-urban (UPA) vegetable farmers in search of water for their crops have no other choice than to use water from these highly polluted sources. This raises public health concerns due to possible crop contamination with pathogens where vegetables are eaten uncooked (Seidu et al., 2008).

Market gardening activity, which is widespread in several African cities, including Cotonou and Parakou, two large cities in Benin, is carried out around the discharge of residual wastewater mainly from slaughterhouses, industries and hospitals. The waste water is often mixed to shallow groundwater which becomes polluted. It should be noted that the reuse of this partially or untreated wastewater constitutes a medium of choice for the development, proliferation and transmission of pathogenic microbes and vectors of diseases such as salmonellosis, malaria, cholera, dysentery, among others (Drechsel and Keraita, 2014). Poorly drained, they can also contaminate groundwater and aquatic environments with dangerous components to living beings. This practice raises concerns for its consequences, particularly on the health of producers and consumers.

Moreover, the fruits and vegetables produced with these waters often contain pathogens that are likely to cause serious public health problems. Regarding this situation, it is urgent to ensure the sanitary condition of the water and market garden products sold to the population. This study was thus undertaken in order to assess the level of contamination of the water and market garden products of the district of Parakou in Benin.

\section{MATERIALS AND METHODS}

\section{Study area}

The research activities took place in Parakou District, Borgou department, one of the municipalities with special status in Republic of Benin. The commune of Parakou is located in the North of the Republic of Benin between the parallels $9^{\circ} 15$ 'and $9^{\circ} 27^{\prime}$ of North latitude and the meridians $2^{\circ} 30$ 'and $2^{\circ}$ $46^{\prime}$ of East longitude. It is the capital of Borgou department and it is located $435 \mathrm{~km}$ from Cotonou. It covers an area of $441 \mathrm{Km}^{2}$. It is bounded to the north by the commune of $\mathrm{N}^{\prime}$ Dali, to the south, east and west by the commune of Tchaourou (Figure 1).

\section{Materials \\ Biological materials}

The biological material consists of:

- Irrigation spring water samples and from the watering cans (Figures 2 and 3);

- Samples of market gardening products (Figure 4) cultivated within the market garden perimeter such as Lactuca sativa (lettuce).

\section{Methods \\ Sampling}

Random sampling was carried out at the site from which we took a total of six (06) samples. Two (02) market gardeners coded 'A' and 'B' were randomly selected and samples were taken from their gardens. For each market gardener four (04) different samples were taken such as: a water from shallow groundwater sample; a sample of water from the watering can, a sample of fresh lettuce and a sample of fresh cabbage. The samples intended for bacteriological analyzes were taken in $250 \mathrm{ml}$ DURAN glass bottles previously sterilized for water samples, and in adiabatic $250 \mathrm{~g}$ plastic packaging for market garden product samples. The bottles were labeled and then coded $A_{1}, A_{2}, A_{3}, A_{4}$ for the market gardener $A$ and, $B_{1}, B_{2}, B_{3}, B_{4}$ for the market gardener $B$. Before the current collection, all the collection containers were previously rinsed two to three times with the 
water to be sampled, to avoid any risk of exogenous contamination. After collection, the samples were kept in a refrigerated enclosure (icebox) at a temperature of $4{ }^{\circ} \mathrm{C}$ and then sent directly to the laboratory for analysis in order to assess the quality of the water used for watering the crops.

\section{Analysis of water samples.}

The pathogenic germs responsible for observed salmonellosis cases in the population and other germs, proof of fecal pollution of water such as Fecal coliforms, Escherichia coli germs, were sought by inoculation in culture media favorable to their isolation.

\section{Microbiological analysis.}

Methods and characteristics of microbiological analysis are summarized in (Table 1) and (Table 2).

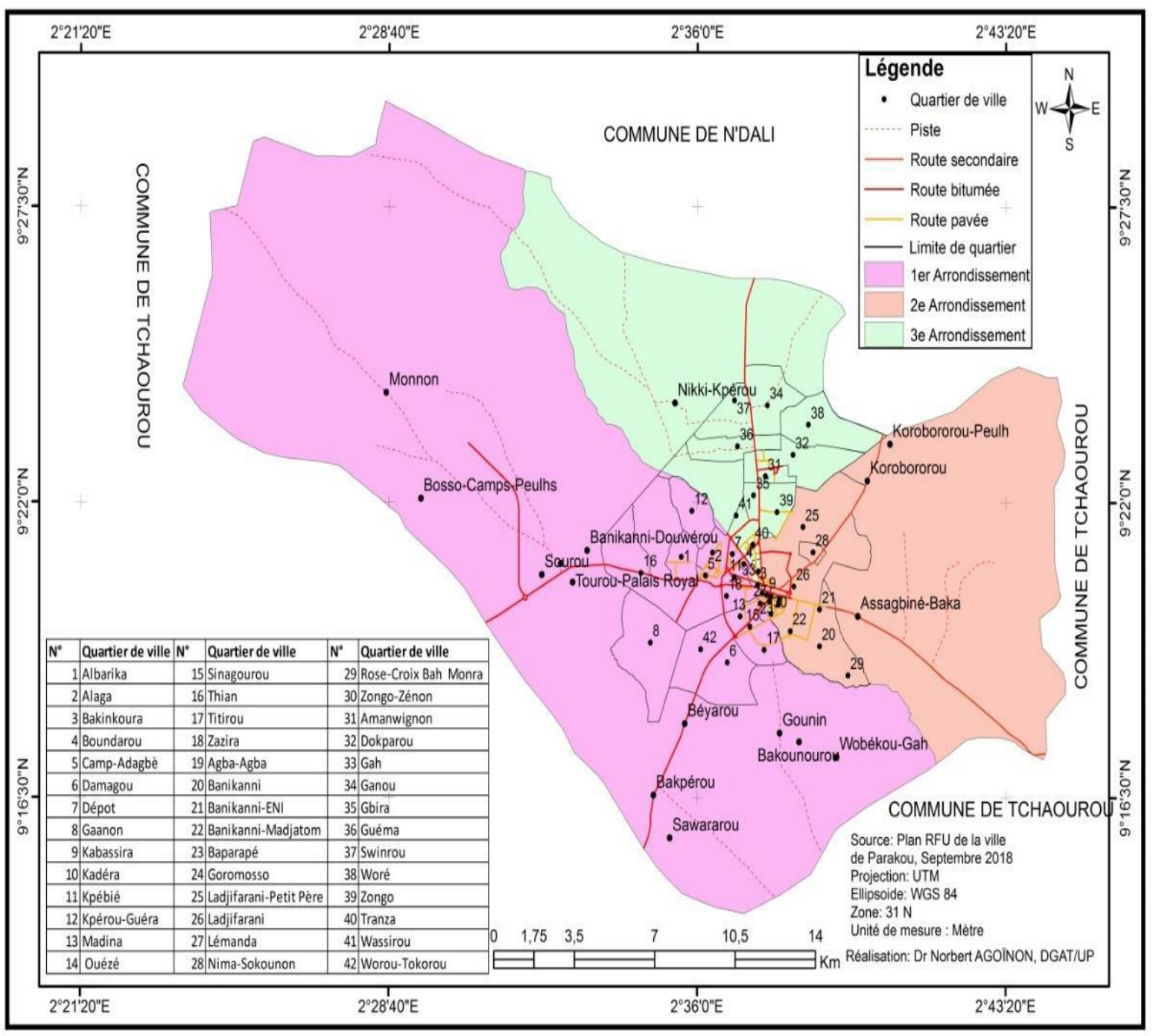

Figure 1: Administrative map of the commune of Parakou. 


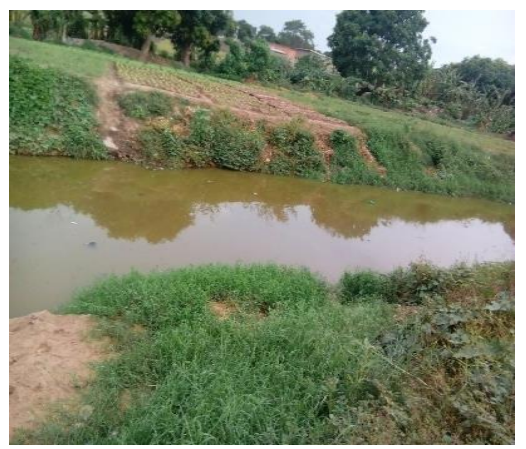

Figure 2: Spring water.

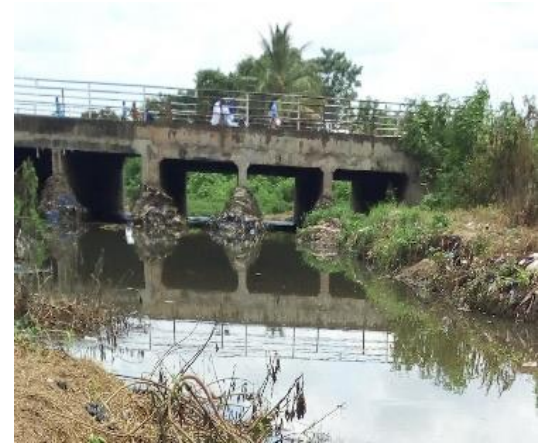

Figure 3: Water collector.

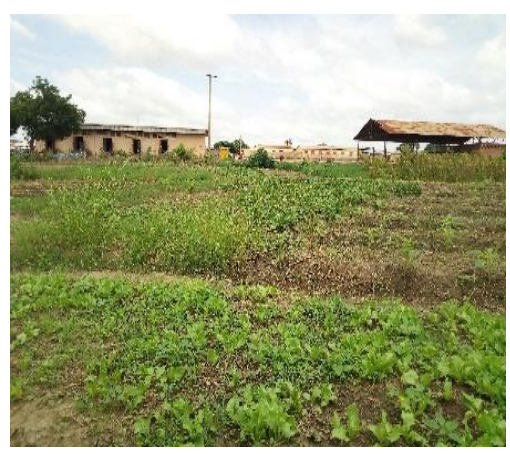

Figure 4: Market garden.

Source: (Nikki, 2019).

Table 1: Characteristics and detection methods for bacteria.

\begin{tabular}{|c|c|c|c|c|}
\hline & Salmonella & Fecal coliforms & E. coli & Staphylococcus aureus \\
\hline Medium Used & SS Agar & $\begin{array}{c}\text { Chrom - } \\
\text { agar ECC at } \\
37^{\circ} \mathrm{C}\end{array}$ & $\begin{array}{c}\text { Chrom - } \\
\text { agar ECC at } \\
37^{\circ} \mathrm{C}\end{array}$ & $\begin{array}{c}\text { Sodium Chloride and Phenol } \\
\text { Red Mannitol Agar }\end{array}$ \\
\hline Incubation Time & & 24 hours & 24 hours & 48 hours \\
\hline $\begin{array}{l}\text { Techniques } \\
\text { Used }\end{array}$ & $\begin{array}{c}\text { Inoculation by } \\
\text { incorporation } \\
\text { into agar }\end{array}$ & $\begin{array}{l}\text { Direct surface } \\
\text { seeding }\end{array}$ & $\begin{array}{l}\text { Direct surface } \\
\text { seeding }\end{array}$ & Direct surface seeding \\
\hline Observation & & Red colonies & Blue colonies & Yellow colonies with halo \\
\hline References & & $\begin{array}{c}\text { AFNOR NF } \\
\text { standard } \\
\text { EN ISO 9308-3 }\end{array}$ & $\begin{array}{c}\text { AFNOR NF } \\
\text { standard } \\
\text { EN ISO 9308-3 }\end{array}$ & - \\
\hline
\end{tabular}

Table 2: Biochemical differentiation tests.

\begin{tabular}{ccccc}
\hline Catalase & Oxidase & $\begin{array}{c}\text { Hemolytic } \\
\text { activity }\end{array}$ & Classic gallery \\
\hline Technical & $\begin{array}{c}\text { Demonstration } \\
\text { of catalytic } \\
\text { activity }\end{array}$ & Strips & $\begin{array}{c}\text { Isolation on } \\
\text { blood agar }\end{array}$ & $\begin{array}{c}\text { Isolation } \\
\text { Observations Kligler, Harnstoff and LIM media. }\end{array}$ \\
$\begin{array}{c}\text { Positive } \\
\text { reaction } \\
\text { when ' there is } \\
\text { turmoil and } \\
\text { negative } \\
\text { otherwise }\end{array}$ & $\begin{array}{c}\text { The Enterobacteriaceae do } \\
\text { not react (colorless) } \\
\text { whereas vibrionnaceae react } \\
\text { (violet color). }\end{array}$ & $\begin{array}{c}\text { Observation } \\
\text { of colonies } \\
\text { after } 24 \\
\text { hours of } \\
\text { incubation } \\
\text { at } 37^{\circ} \mathrm{C}\end{array}$ & $\begin{array}{c}\text { Color or gas release reaction } \\
\text { depending on the medium and the } \\
\text { microorganism }\end{array}$ \\
\hline
\end{tabular}




\section{RESULTS}

The results of the various bacteriological analysis, from the detection of salmonella to their selective identification, including the search for other fecal germs which indicate fecal pollution are given in the tables below.

\section{Results of the search for Salmonella in all samples}

The results of the search for germs (Salmonella) on all the samples that were analyzed (Table 3). Levels of Salmonella contamination vary significantly depending on solid, liquid or semi-solid culture media. These pathogenic germs to humans, S. typhi, $S$. paratyphi and others are found abundantly in all samples whether at the shallow groundwater, at the watering can or at the level of the market garden products.

Salmonella strains can be confused with some Enterobacteriaceae, due to the similarity of some of their biochemical characters. To differentiate these strains close to Salmonella, therefore, presumption tests were carried out, with the aim of identifying the characters of Salmonella's genus. For the present study, it consists in the demonstration of catalytic activity, hemolytic activity and oxidase test.

\section{Result of the catalytic activity test}

A positive catalytic activity was noted on all the samples analyzed (Table 4). An effervescent reaction between the colonies of isolated germs and a drop of hydrogen peroxide was also observed. This reaction is characteristic of the presence of pathogenic Salmonella in human organism. A positive catalytic activity was noted on all the samples analyzed. An effervescent reaction between the colonies of isolated germs and a drop of hydrogen peroxide was also observed. This reaction is characteristic of the presence of pathogenic Salmonella in the human organism.

\section{Result of the hemolytic activity test}

This test reveals that germs present in the samples analyzed after 24 hours of incubation at $37{ }^{\circ} \mathrm{C}$ do not have haemolytic power (Table 5). Non-haemolytic germs are known to be pathogenic because they are able to cause leukopenia.

\section{Result of the oxidase test}

The test for oxidase is a fundamental test to guide the identification of Salmonella types. It emerges that all the germs identified do not react to the oxidase test because the strip used has remained colorless, otherwise it should have a purple color (Table $6)$.

In addition to these identification tests for the different types of pathogenic germs (Salmonella), other confirmation tests are performed. It was carried out by inoculation in four media, namely Kligler medium, ureaindole medium, glycerol medium and Taylor's lysine "LDC" medium. The results obtained are as follows:

\section{Biochemical characteristics of some Salmonella}

The biochemical test (Table 7) shows that the isolated salmonella are those which mainly affect the human organism (Salmonella typhi and paratyphi), and the minor Salmonella (enteritidis and murium) contributing to the risk of salmonellosis.

\section{Bacteriological analysis of Fecal coliforms and E. coli}

Our research also pointed out the nonnegligible presence of other types of pathogenic germs which were the subject of study in the samples (Table 8).

This Table shows test results from shallow spring water and vegetable samples. Analysis of fecal contamination indicators (Fecal coliforms and E. coli) carried out on our samples at the market gardening site show significant pollution levels. Untreated wastewater contains a variety of excreted organisms, including pathogens, the types and numbers of which depend on the background levels of corresponding infections in population. E. coli and Fecal coliforms are used as indirect indicators of pathogenic agents with similar characteristics and may be present in waste water. 
Table 3: Results of the search for Salmonella in all samples.

\begin{tabular}{|c|c|c|}
\hline Sampling points & Sample code & $\begin{array}{l}\text { Amount of colonies on media } \\
\text { (Presence of Salmonella) }\end{array}$ \\
\hline \multirow[t]{2}{*}{ Spring water } & A1 & ++++ \\
\hline & B1 & ++++ \\
\hline \multirow[t]{2}{*}{ Watering can } & $\mathrm{A} 2$ & +++ \\
\hline & B2 & +++ \\
\hline \multirow[t]{4}{*}{ Market garden products } & A3 & ++ \\
\hline & A4 & ++ \\
\hline & B3 & ++ \\
\hline & B4 & ++ \\
\hline
\end{tabular}

Table 4: Result of the catalytic activity test: differentiation from other types of Salmonella.

\begin{tabular}{ccc}
\hline Sampling points & Sample codes & Catalase test \\
\cline { 2 - 3 } & & Catalase $(+)$ \\
\hline Spring water & A1 & + \\
\cline { 2 - 3 } & B1 & + \\
Watering cans & A2 & + \\
\cline { 2 - 3 } & B2 & + \\
\hline Market garden products & A3 & + \\
\cline { 2 - 3 } & A4 & + \\
\cline { 2 - 3 } & B3 & + \\
\hline & B4
\end{tabular}

Table 5: Result of the hemolytic activity test.

\begin{tabular}{cccc}
\hline Sampling points & Sample code & \multicolumn{2}{c}{ Hemolysis test } \\
\cline { 2 - 4 } & & Hemolysis ( +) & Hemolysis ( -) \\
\hline \multirow{2}{*}{ Spring water } & A1 & None & - \\
\cline { 2 - 4 } & B1 & None & - \\
\hline Watering can & A2 & None & - \\
\cline { 2 - 4 } & B2 & None & - \\
Mroducts & A3 & None & - \\
\cline { 2 - 4 } & A4 & None & - \\
\cline { 2 - 4 } & B3 & None & - \\
\hline
\end{tabular}

$+=$ Positive reaction; $-=$ no reaction. 
Table 6: Result of the oxidase test: identifications of other types of Salmonella.

\begin{tabular}{cccc}
\hline Sampling points & Sample code & \multicolumn{2}{c}{ Oxidase test } \\
\cline { 2 - 4 } & & Oxidase $(+)$ & Oxidase ( -) \\
\hline Spring water & A1 & None & - \\
\cline { 2 - 4 } & B1 & None & - \\
\hline Watering cans & A2 & None & - \\
\cline { 2 - 4 } Market garden \\
products & B2 & None & - \\
\cline { 2 - 4 } & A3 & None & - \\
\cline { 2 - 4 } & A4 & None & - \\
\cline { 2 - 4 } & B3 & None & - \\
\hline
\end{tabular}

Table 7: Biochemical characteristics of some Salmonella.

\begin{tabular}{c|ccccccc} 
Bacteria & Indol & Urea & Carbohydrate & Lake & $\mathbf{H}_{2} \mathbf{S}$ & Mobility & LDC \\
\hline $\begin{array}{c}\text { Salmonella } \\
\text { typhimurium }\end{array}$ & - & - & + & - & $+/-$ & + & + \\
$\begin{array}{c}\text { Salmonella } \\
\text { enteritidis }\end{array}$ & - & - & + & - & + & + & + \\
$\begin{array}{c}\text { Salmonella } \\
\text { typhi }\end{array}$ & - & - & + & - & $+/-$ & + & + \\
$\begin{array}{l}\text { Salmonella } \\
\text { para typhi }\end{array}$ & - & - & + & - & + & + & + \\
\hline \\
+ + positive reaction; - = negative reaction; & $++/-=$ neutral reaction.
\end{tabular}

Table 8: Results of bacteriological analysis of fecal coliforms and E. coli.

\begin{tabular}{|c|c|c|c|}
\hline \multirow{2}{*}{ Sampling point } & \multirow[t]{2}{*}{ Sample code } & \multicolumn{2}{|c|}{ Other germs } \\
\hline & & Fecal coliforms & E. coli \\
\hline \multirow[t]{2}{*}{ Spring water } & A1 & +++ & +++ \\
\hline & B1 & +++ & +++ \\
\hline \multirow{4}{*}{$\begin{array}{l}\text { Market garden } \\
\text { products }\end{array}$} & A3 & + & + \\
\hline & A4 & + & + \\
\hline & B3 & + & + \\
\hline & B4 & + & + \\
\hline
\end{tabular}

$+++=>85 \% ;+=>50 \%$. 


\section{DISCUSSION}

The results obtained in this work show a total contamination of water and vegetable products by Salmonella. The presence of Salmonella and Fecal streptococci in the water and market garden products of Parakou rises a major public health problem. Indeed, the high levels of bacteriological pollution found in the irrigation water of the site can be explained by a certain number of factors such as the nonfunctioning of the purification stations, the use of the site as an unauthorized dumping place for household waste due to their proximity to the Arzèkè international market in Parakou, the intensive use of fertilizers from slaughterhouse animals or the existence of many sources of pollution. This supposes that users of this market who would have come from other regions and which would harbor dangerous germs such as Salmonella typhi could exacerbate the risk of contamination of this irrigation water. Some behavior of the populations is also to be deplored, in particular, direct defecation on the site. This polluted nature of the resource, logical result of sources pollution, shows the important vulnerability of the populations exposed to these waters in the context of market gardening activities. These observations are consistent with those of Jiménez et al. (2009), who specifies that water pollution in metropolitan areas in developing countries is mainly the result of faulty sanitation. As such, the resurgence of water-borne diseases in general which affect market gardeners as well as retailers and consumers might be explained. This correlation between poor water quality and the resurgence of water-borne diseases has been studied by several authors in various cities in developing countries. This is the case, among others, of Drechsel and Keraita (2014) in Ghana, Rutkowski et al. (2007) in Katmandu, Trang et al. (2007) in Northen Vietnam.

The different identification and differentiation tests of Salmonella such as oxidase, catalase, haemolytic and other tests have enabled the detection among the Salmonella identified, those which are pathogenic to humans and which are likely to cause leukopenia and other damage to the body. These results are consistent with those of Manfredi et al. (2001), who showed that non-hemolytic bacteria can induce leukopenia in humans. Hemolytic bacteria have transparent voids around them, while nonhemolytics (Enterobacteriaceae) do not. The same observation was made by Haeghebaert et al. (2001). Moreover, our results confirmed those of Djegbe et al. (2018) who, at the end of their work carried out on the same market gardening site in Parakou, indicate that irrigation water and vegetables have total coliform and fecal contents exceeding required standards. The use of these vegetables poses a threat to the health of the market gardeners themselves as well as that of the population consuming market garden products.

It should be noted that there is no perfect indicator organism for wastewater, especially for non-fecal bacterial pathogens, helminths, viruses and protozoa, since concentrations of fecal indicator bacteria do not often match the concentrations of these organisms. Our study therefore did not take into account other types of contamination. Also, if wastewater- based effluents had been chlorinated, this operation would have reduced the concentrations of bacteria considerably, but not to the same degree as the concentrations of viruses, protozoa and helminths.

The ignorance of some market gardeners increases other forms of contamination. Wognin et al. (2014) in Côte d'Ivoire, stated that $73.4 \%$ of producers are not aware of the risks of contamination due to their behavior, compared to $8.3 \%$ who claim to recognize their share of responsibility for the contamination of market garden products. Given the levels of microbiological contamination observed, the geographical location and human activities, they could have other types of contamination. This point is confirmed by some authors who have carried out research on a few market garden sites in Benin such as Atidegla et al. (2011) and Agueh et al. (2015). These authors reported the presence of heavy metals in irrigation water and in market garden products. They also 
suggested that different levels reveal the existence of a causal relationship between nonagricultural human activities and the levels of contamination. However, it is urgent to find approaches which could reduce these contaminations through sensitization. The professional awareness of market gardeners should be raised and the application of specific treatments such as heat or disinfection treatments to fresh market garden products by the population before their consumption. Yehouenou et al. (2020) showed that cooking vegetables leads to a considerable reduction in heavy metal content, which reduces the health risk for the consumer in Cotonou (Benin).

\section{Conclusion}

This study pointed out not only the current state of production of market garden products but also the level of bacteriological contamination of the irrigation water used in the district of Parakou, more precisely at the level of slaughterhouse site. The risks for market gardeners in close contact with these products and consumers buying them were also mentioned. Our research showed a huge contamination of wastewater used for watering plants and vegetables from crops by pathogenic bacteria (Salmonella). The polluted nature of this environment represents a health risk factor for the population. In order for this form of agriculture to continue to meet the food needs of a large number of the populations while reducing health risks, this type of activity should be taken into account in urban development strategies. This requires better management of wastewater by industries, good supervision and awareness of farmers on cultivation techniques, and the development of shallows. Good coordination of all actors and involved services is therefore essential.

\section{COMPETING INTERESTS}

The authors declare that they have no competing interests.

\section{AUTHORS' CONTRIBUTIONS}

EBNS wrote the original draft under the supervision of ASYH. VNA and EBNS made the experimental design. ABS, VNA and
EBNS carried out field work, data collection and laboratory analysis. AFB and ASYH treated the data, edited and formatted the manuscripts. ASYH is the corresponding author.

\section{ACKNOWLEGEMENTS}

We wish to acknowledge the Laboratory of Hydraulic Service of Parakou for enabling environment to carry out the experiments described in this work.

\section{REFERENCES}

Agueh V, Degbey C, Sossa-Jerome C, Adomahou D, Paraiso M, Vissoh S, Fayomi B. 2015. Contamination level of market garden products by toxics at Houéyiho in Benin. Int. J. Biol. Chem. Sci., 9(1): 542-551. DOI: http://dx.doi.org/10.4314/ijbcs.v9i1.46

Atidegla S, Agbossou E, Huat J, Glele Kakai R. 2011. Metal contamination of vegetables in urban and peri-urban market garden areas: Case of the municipality of Grand - Popo in Benin. Int. J. Biol. Chem. Sci., 5(6): 2351-2361. DOI: http://dx.doi.org/10.4314/ijbcs.v5i6.15

Djegbe I, Tamou-Tabe TS, Topanou N, Soglo FM, Paraiso A, Djouaka R, Kelome CN. 2018. Seasonal variation of physicochemical and microbiological quality of irrigation water and vegetables at the Bawera market garden site and associated health risks. Int. J. Biol. Chem. Sci., 12(2): 781-795. DOI: https://dx.doi.org/10.4314/ijbcs.v12i2.13

Drechsel P, Graefe S, Sonou M, Cofie OO. 2006. Informal Irrigation in Urban West Africa: An Overview. Research Report 102, International Water Management Institute (IWMI), Colombo, Sri Lanka, p.40.

Drechsel P, Keraita B. 2014. Irrigated Urban Vegetable Production in Ghana: Characteristics, Benefits and Risk Mitigation. Research Report, International Water Management Institute (IWMI), Colombo, Sri Lanka, p.247.

Haeghebaert S, Duché L, Gilles C, Masini B, 
Dubreuil M, Minet JC, Vaillant V. 2001. Minced beef and human salmonellosis: review of the investigation of three outbreaks in France. Euro Surveill., 6(2): 21-26.

DOI: https://doi.org/10.2807/esm.06.02.00223 -en

Jiménez B, Mara D, Carr R, Brissaud F. 2009. Wastewater Irrigation and Health. Research Report, International Water Management Institute (IWMI), Colombo, Sri Lanka.

Kenmogne GRK, Rosillon F, Mpakam HG, Nono A. 2010. Health, socio-economic and environmental issues linked to the reuse of wastewater in urban market gardening: case of the Abiergué watershed (Yaoundé-Cameroon). VertigO, 10(2): 10323. DOI: https://doi.org/10.4000/vertigo.10323

Manfredi R, Nanetti A, Ferri M, Chiodo F. 2001. Enterobacter spp. infections complicating the course of HIV disease. $J$. Chemother., 13(2): 195-201. DOI: https://doi.org/10.1179/joc.2001.13.2.195

Rutkowski T, Raschid-Sally L, Buechler S. 2007. Wastewater irrigation in the developing world-Two case studies from the Kathmandu Valley in Nepal. Agric. Water Manag., 88(1): 83-91 DOI: https://doi.org/10.1016/j.agwat.2006.08.
012

Seidu R, Heistad A, Amoah P, Drechsel P, Jenssen PD, Stenström TA. 2008. Quantification of the health risk associated with wastewater reuse in Accra, Ghana: A contribution toward local guidelines. J. Water Health, 6(4): 461-471.

DOI: https://doi.org/10.2166/wh.2008.118

Trang DT, Hoek W, Tuan ND, Cam PD, Viet VH, Luu DD, Dalsgaard A. 2007. Skin disease among farmers using wastewater in rice cultivation in Nam Dinh, Vietnam. Trop. Med. Int. Health., 12(2): 51-58. DOI: https://doi.org/10.1111/j.13653156.2007.01941.x

Wognin A, Ouffoue S, Assemand E, Tano K, Koffi-Nevry R. 2014. Perception of health risks in market gardening in Abidjan, Côte d'Ivoire. Int. J. Biol. Chem. Sci., 7(5): 1829-1837. DOI: https://doi.org/10.4314/ijbcs.v7i5.4

Yehouenou Azehoun Pazou E, Azehoun Pazou JA, Adamou MR. 2020. Determination of heavy metals in the soil and market garden products at the Houéyiho market garden site in Benin. Int. J. Biol. Chem. Sci., 14(5): 1893-1901. DOI: https://doi.org/10.4314/ijbcs.v14i5.31. 